\title{
Increased psychological trauma and decreased desire to have children after a complicated pregnancy
}

\author{
Komplike gebelik sonrası artan psikolojik travma ve azalan çocuk isteği arzusu
}

Pınar Tan ${ }^{1}$, Mehmet Sıddık Evsen ${ }^{1}$, Hatice Ender Soydinç ${ }^{1}$, Muhammet Erdal Sak ${ }^{1}$, Ali Özler ${ }^{1}$, Abdulkadir Turgut $^{1}$, Yasin Bez ${ }^{2}$, Talip Gül ${ }^{1}$

'Department of Obstetrics and Gynecology, School of Medicine, Dicle University, Diyarbakir, Turkey

${ }^{2}$ Department of Psychiatry, School of Medicine, Dicle University, Diyarbakur, Turkey

\section{Abstract}

Objective: Information about fertility desire and psychological sequelae after high-risk pregnancies are scarce in the literature. The aim of the present study is to investigate the psychological effects of high-risk pregnancies.

Material and Methods: The patients who had a history of severe preeclampsia, eclampsia or major hemorrhage during the peripartum period were enrolled as the study group and compared with the control subjects with respect to fear about new pregnancy, anxiety/ depression and post-traumatic stress disorder (PTSD) scores. The study was carried out by submitting a questionnaire form to the participants. Numbers of planned children before and after the last delivery were evaluated in both groups.

Results: Fear about a new pregnancy was found to be significantly higher in the study group compared with the controls. There were no statistically significant difference between the two groups in terms of anxiety and depression. In terms of re-experience and avoidance in PTSD was significantly higher in the study group, however no significant difference was found for hyper-arousal.

Conclusion: Fear regarding new pregnancy is high and planning more children is decreased after high-risk pregnancies and PTSD symptom scores were higher after high-risk pregnancies.

(J Turkish-German Gynecol Assoc 2013; 14: 11-4)

Key words: Pregnancy, fear of childbirth, depression, post traumatic stress syndrome, anxiety

Received: 2 November, 2012

Accepted: 15 January, 2013
Özet

Amaç: Yüksek riskli gebelik sonrasında tekrar çocuk sahibi olma isteği ve psikolojik sekel riski literatürde yeteri kadar mevcut değildir. Bu çalışmanın amacı yüksek riskli gebelik sonrasında psikolojik etkileri incelemektir.

Gereç ve Yöntemler: Peripartum dönemde şiddetli preeklampsi, eklampsi veya doğuma bağlı majör kanama öyküsü olan hastalar; gebelik korkusu, travma sonrası stres bozukluğu (TSSB) ve anksiyete /depresyon skorları bakımından kontrol grubu ile karşılaştırıldı. Çalışmaya katılan hastalara birebir yüz yüze anket yöntemi ile formlar dolduruldu. Son doğum öncesi ve sonrası planlanan çocuk sayısı her iki grupta değerlendirildi.

Bulgular: Hasta grubunda tekrar gebe kalma korkusu kontrol grubuna göre önemli bir şekilde yüksek izlendi. Anksiyete ve depresyon skorları açısından iki grup arasında istatistiksel anlamlı fark izlenmedi. Hasta grubunda kontrol grubuna göre TSSB açısından; yeniden yaşam ve kaçınma belirtileri istatistiksel anlamlı yüksek iken, uyarılmışlık açısından fark gözlenmedi.

Sonuçlar: Komplike gebelik yaşamış hastalarda yeni bir gebeliğe karşı korku yüksek olmakta ve sonuç olarak planlanan çocuk sayısında azalmaya neden olmaktadır. Komplike gebelik sonrası hastalar TSSB semptomları gelişmesi yönünden risk altındadırlar.

(J Turkish-German Gynecol Assoc 2013; 14: 11-4)

Anahtar kelimeler: Gebelik, çocuk doğurma korkusu, depresyon, travma sonrası stres bozukluğu, anksiyete

Geliş Tarihi: 2 Kasım 2012

Kabul Tarihi: 15 Ocak 2013

\section{Introduction}

Every mother has significant memories about the course of the pregnancy/delivery (P/D) period. The mother and fetus could be exposed to complications and risks related to pregnancy and/or delivery, which can be described as high-risk pregnancies or complicated P/D. Maternal/fetal morbidity and mortality is high in complicated $\mathrm{P} / \mathrm{D}$ (1). It has been reported that the most common pregnancy complications that require intensive care unit and the leading causes of maternal complications and mortality are preeclampsia/eclampsia and major peripartum hemorrhage (PPH) during the peripartum period (2-5).
Past experiences of an individual have substantial effects on his or her future decisions. It could be anticipated that a complicated pregnancy that leads to life-threatening conditions, prolonged hospital stays and additional interventions may cause fear related to repeated pregnancy or delivery. The negative effects and the risk of a repetition of the experience may lead to reluctance to have a child. The desire to have a child may change based on various factors such as the number of children one has, the society, economic status, education and past experiences. To our knowledge, studies about the future desire of the patients with history of complicated P/D to have a child are lacking in the literature. 
In the present study, we aimed to investigate the desire for a new pregnancy and more children, also the anxiety/depression and post-traumatic stress disorder (PTSD) symptoms in patients with a history of complicated $\mathrm{P} / \mathrm{D}$, and to compare them with those of control subjects.

\section{Material and Methods}

This prospective study was conducted in the Obstetrics and Gynecology clinics of Dicle University Hospital, which is a tertiary referral center in the southeast Anatolian region, where complicated P/D cases are frequently referred. The patients who had severe preeclampsia or eclampsia or major hemorrhage during the peripartum period between January 2008 and December 2010 were enrolled as the study group. We used the term "complicated P/D" to simplify the analysis. The study and control groups included patients who were aged from 18 to 35 years, have no more than 3 children, have not reached her previously desired family size, had their last delivery within 6 months to 2 years and have completed at least primary school education and had no history of psychiatric disorder and psychotropic drug use. From patient records, 114 patients who were followed-up/treated in our clinic for complicated P/D were identified (Figure 1). These patients were interviewed via telephone calls and were informed about the study on January and February 2011. Forty patients who met the inclusion criteria and agreed to be enrolled in the study were invited to the clinic and participated in the study between January and April 2011. In the study group, 14 patients had severe preeclampsia, 14 patients had eclampsia and 12 patients had major hemorrhage histories during their peripartum period. Forty-one women, who were delivered at our clinic and did not have a history of complicated P/D, were enrolled as the control group.

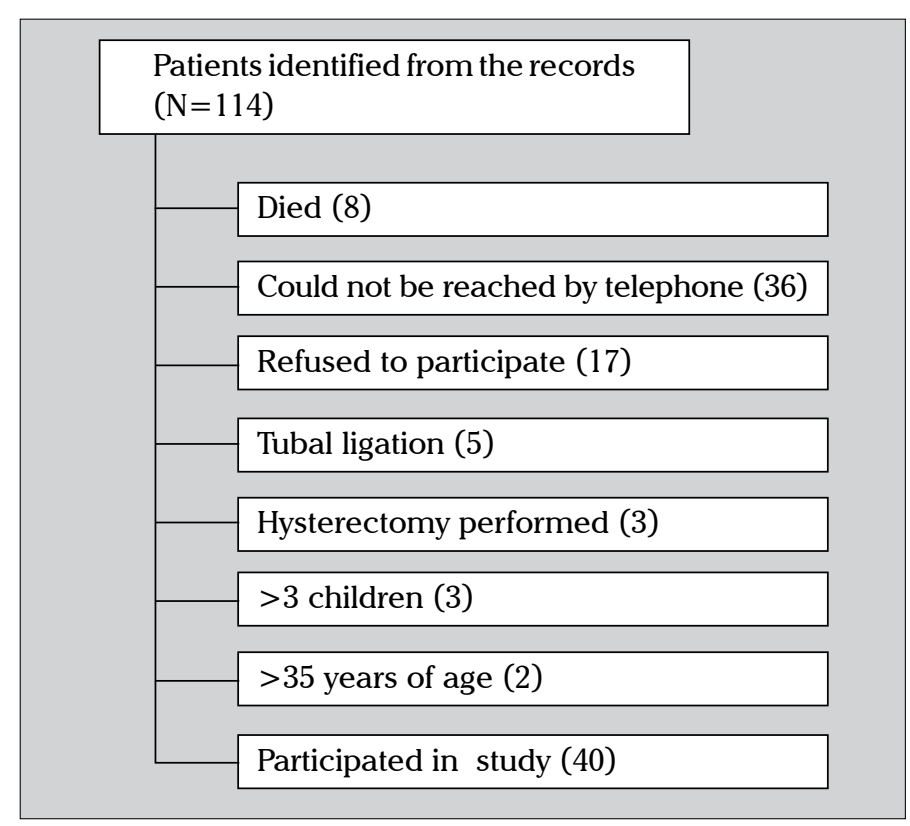

Figure 1. Distribution of the status of the patients identified from medical records at the time of recruitment to the study and selection of the study population
For each participant, hospital stay during the course of the last $\mathrm{P} / \mathrm{D}$, age, gravida, parity, number of living children, number of planned children before and after birth were identified. Their fear of a new pregnancy, depression/anxiety levels and PTSD symptoms were measured by questionnaires. All participants gave written informed consent. The study was approved by the Medical Ethics Committee of Dicle University.

\section{Analog scale for evaluating the fear of a new pregnancy}

The scale was developed by the investigators to measure the fear of getting pregnant again by rating. The scale was designed as a fear scale (FS) which is a $10 \mathrm{~cm}$ long horizontal straight line with $1 \mathrm{~cm}$ gaps between each rating, starting from 0 (not worried at all) and continuing up to 10 (very worried). It was adapted from a visual analogue scale (VAS) used to measure severity of pain subjectively (6). The patients could mark the level of fear they have regarding a repeat pregnancy by marking between 0 and 10 on the scale. It was a self-reported scale, that measured fear of a new pregnancy subjectively.

\section{Hospital anxiety and depression scale (HADS)}

The HADS was first developed by Zigmond at al. (7) 1983. It consists of 14 questions with multiple choices. It provides two subscores (anxiety and depression) and a total score. It is accepted as a reliable and valid scale for assessing clinically significant anxiety and depression (8). Higher scores reflect worse anxiety and depression. The HADS total score is also a valid measure of "emotional distress" or "psychological distress", so that the HADS can be used as a measure of overall psychiatric morbidity (9). The validity and reliability of the Turkish version of HADS was demonstrated by Aydemir et al. (10).

\section{PTSD checklist-civilian version (PCL-C)}

The PCL-C is an easily administered scale designed to assess the symptoms of posttraumatic stress disorder according to Diagnostic and Statistical Manual of Mental Disorders, $4^{\text {th }}$ Edition DSM-IV criteria. It consists of 17 items with Liekert type answers ranging from 1 to 5 . It is a self-report scale and provides three subscale scores (re-experience, avoidance, and hyper-arousal) and a total score. Higher scores reflect more severe symptoms of PTSD (11). The validity and reliability of the Turkish version of PCL-C was demonstrated by Kocabasoglu et al. (12).

\section{Statistical analyses}

Statistical analyses of the obtained data were conducted by using Statistical Package for Social Sciences (SPSS) version 15.0 (Chicago, IL, USA). Descriptive statistics were used to define the demographic data of the participants. Frequency and percentage were calculated if the data was categorical, whereas mean and standard deviation were calculated if they were continuous. For the comparison of continuous variables between groups, independent samples t test was used. The dependent samples t test was used to assess possible differences between any two repeated measures in a single group. Normality of variance was tested with the Kolmogorov-Smirnov test. Variables showing non-parametric distribution were compared between groups by using the Mann-Whitney U test. For the comparison 
of categorical variables between groups, the Chi-square test was used. A P value less than 0.05 was accepted as statistically significant.

\section{Results}

The mean ages of the study and control groups were $26.98 \pm 4.45$ and $28.07 \pm 4.44$ years respectively $(p=0.26)$. Demographical characteristics of patients showed no statistically significant difference between the groups (Table 1). In the study group, mean hospital stay due to complicated P/D was $11.73 \pm 11.42$ days. In the study group, 34 cases (85\%) reported fear of having a new pregnancy, whereas 21 (51.2\%) cases reported the same fear in the control group $(\mathrm{p}=0.001)$. Fear scale scores about a new pregnancy was $7.22 \pm 3.86$ in the study group, whereas it was $4.12 \pm 3.80$ in the control group $(\mathrm{p}<0.001)$. The mean number of planned children in the study group were $3.75 \pm 1.15$ before the complicated P/D whereas it had declined to $1.60 \pm 1.41$ afterwards. In the control group the planned number of children had also decreased after normal P/D (Table 2). Moreover, the decline in the study group was statistically greater than that of control subjects $(\mathrm{p}<0.001)$. No statistically significant difference was observed when the groups were compared in terms of anxiety and depression. PTSD scorings of re-experience and avoidance symptoms, and total scores were significantly higher in the patient group; however, no statistical difference was observed between the groups in terms of hyper-arousal symptoms (Table 3 ).

\section{Discussion}

The present study showed a statistically significant decline in desired family size after complicated P/D. In cases with major $\mathrm{PPH}$, who had hypogastric artery ligation (13), uterine artery

Table 1. Demographical characteristics of the groups (Mean \pm Standard Deviation)

\begin{tabular}{|l|c|c|c|}
\hline & $\begin{array}{c}\text { Study group } \\
(\mathbf{n = 4 0 )}\end{array}$ & $\begin{array}{c}\text { Control group } \\
(\mathbf{n = 4 1 )}\end{array}$ & $\boldsymbol{p}$ \\
\hline Age (years) & $26.98 \pm 4.45$ & $28.07 \pm 4.44$ & 0.27 \\
\hline Gravidity & $2.80 \pm 1.42$ & $2.24 \pm 1.20$ & 0.06 \\
\hline Parity & $2.15 \pm 1.12$ & $1.90 \pm 0.83$ & 0.26 \\
\hline $\begin{array}{l}\text { Number of } \\
\text { living children }\end{array}$ & $1.78 \pm 0.95$ & $1.88 \pm 0.81$ & 0.60 \\
\hline
\end{tabular}

Table 2. Planned number of children in both groups before and after their last pregnancy (Mean \pm Standard Deviation)

\begin{tabular}{|l|c|c|c|}
\hline & $\begin{array}{c}\text { Planned number } \\
\text { of children before } \\
\text { last pregnancy }\end{array}$ & $\begin{array}{c}\text { Planned number } \\
\text { of children after } \\
\text { last pregnancy }\end{array}$ & $\boldsymbol{p}$ \\
\hline $\begin{array}{l}\text { Study group } \\
(\mathrm{n}=40)\end{array}$ & $3.75 \pm 1.15$ & $1.60 \pm 1.41$ & $<0.001$ \\
\hline $\begin{array}{l}\text { Control group } \\
(\mathrm{n}=41)\end{array}$ & $2.78 \pm 0.96$ & $1.98 \pm 1.37$ & 0.001 \\
\hline
\end{tabular}

embolisation (14), or uterine devascularization (15) and whose fertility was preserved, when future pregnancy results were evaluated, it has been observed that the patients' future desire to have more children had declined. Investigators claimed that the women who have undergone serious risks tend to have reluctance to childbirth due to their anxiety of having the same risks again and that this decline is anticipated to have psychological reasons (13-15).

There were $85 \%$ patients in the study group and $51.2 \%$ patients in the control group who had a fear of having a new pregnancy, and the difference was statistically significant. We were unable to find a scale designed or recommended to measure fear caused by previous experiences. Therefore, we used a FS, which was modified from the VAS scale. While this method is open to discussion, understanding and application of this method is easy. The desire to become pregnant again might have decreased in complicated $\mathrm{P} / \mathrm{D}$ cases due to prolonged hospital stay, exposure to additional trauma, life threatening nature of prior pregnancy, and the likelihood and fear of being exposed to the same risks again. The significantly higher degree in FS in the complicated P/D group, compared to the control group gives rise to the thought that this might be related to the experienced risk. The decrease in the desired family size after $\mathrm{P} / \mathrm{D}$ in both groups makes it plausible that any pregnancy affects the patient's desire, and its impact increases with additional complications. The present study showed that desire to have more children after normal or complicated P/D has declined. However, the decline in the study group was higher when compared to the control group.

The groups were not different in terms of depression and anxiety levels. This condition can be explained in several ways. First, even if depression and anxiety symptoms had developed in patients, these might have healed in time due to various reasons. Second, even if the $\mathrm{P} / \mathrm{D}$ experience was normal or complicated, it might lead to similar impact in terms of depression and anxiety symptoms. In addition, both conditions can lead to development of PTSD symptoms instead of depression and anxiety.

PTSD is defined as "one experiencing a direct exposure to a severe traumatic, stressing situation that may lead to a death

Table 3. Anxiety/Depression and Posttraumatic stress disorder symptom scores in both groups (Mean \pm Standard Deviation)

\begin{tabular}{|l|c|c|c|}
\hline & $\begin{array}{c}\text { Study group } \\
(\mathbf{n = 4 0 )}\end{array}$ & $\begin{array}{c}\text { Control group } \\
(\mathbf{n = 4 1 )}\end{array}$ & $\boldsymbol{p}$ \\
\hline HADS Anxiety & $8.55 \pm 4.31$ & $8.15 \pm 4.15$ & 0.66 \\
\hline HADS Depression & $6.18 \pm 3.79$ & $6.68 \pm 4.45$ & 0.59 \\
\hline HADS Total & $14.75 \pm 7.3$ & $14.61 \pm 7.92$ & 0.93 \\
\hline PTSD re-experience & $15.00 \pm 4,12$ & $12.24 \pm 5.55$ & 0.013 \\
\hline PTSD avoidance & $18.35 \pm 5.11$ & $15.30 \pm 5.50$ & 0.011 \\
\hline PTSD hyper-arousal & $14.13 \pm 4.50$ & $12.80 \pm 4.31$ & 0.17 \\
\hline PTSD total & $47.48 \pm 11.78$ & $40.56 \pm 13.21$ & 0.015 \\
\hline HADS: Hospital anxiety depression scale, PTSD: Posttraumatic stress disorder \\
\hline
\end{tabular}


risk or serious dysfunction, and he/she is responding to this experience with intense fear, helplessness and concern". Diagnosis of PTSD might be difficult in the postpartum period due to hormonal changes and adaptation mechanisms (16). Patients who have a history of general anxiety, incapacity to manage stress, fear inspired by delivery experience and psychiatric disorder may have a higher risk of developing PTSD (17). Olde et al. (18) have reported individuals who have poor social support, more obstetric intervention, perceived or true negative attitude of health-care personnel, and negative emotional state during pregnancy or postpartum period as a high-risk group in terms of PTSD. Although traditionally, childbirth is not considered as an event that initiates PTSD symptoms, Beck et al. (19) reported that it can lead to severe traumatic stress and can contribute to developing PTSD. Maggioni et al. (20) have reported that patients who perceive their normal delivery as being traumatic had developed PTSD and described that delusional fears can surpass reality at times. Compared to the control group, we found significantly higher levels of re-experience and avoidance symptoms and total scores in the patient group. Post-traumatic stress disorder hyper-arousal symptoms were similar in both groups.

This study has some limitations. The mall sample size of the study prohibits generalizability of the results. Additionally, it would be better if the evaluations of the patients were performed immediately after the obstetrical event and also in a second interview after a predetermined time period, which would give two scores and a better evaluation of the scales. Further studies are welcomed to clarify this issue.

As a result, fear of undergoing a new pregnancy was higher among those who had history of complicated P/D when compared to those with a history of normal $\mathrm{P} / \mathrm{D}$, and this condition appears to be associated with decreased desire to have more children. Although a decline is also observed in the number of children wanted in the normal P/D experiences, this decline appears to be lower compared with complicated P/D experiences. In addition to the $\mathrm{P} / \mathrm{D}$ experiences, the number of children planned can be affected by other factors such as the number of children present, parental desire, socio-economic status, and religious and societal views. On the other hand, while normal and complicated P/D patients display similar traits in terms of depression and anxiety, those who have a history of complicated P/D report having more severe symptoms of posttraumatic stress disorder. Further work is needed to explain in detail how this condition impacts the number of planned children.

\section{Conflict of interest}

No conflict of interest was declared by the authors.

\section{References}

1. Coppens M, James D. Organization of prenatal care and identification of risk. In: High-risk Pregnancy Management Options, James DK, Steer PJ, Weiner CP, Gonik B. eds. Second edition. W.B. Saunders. 1999; 11-22.

2. Baskett TF, MB, O'Connell CM. Maternal critical care in obstetrics. J Obstet Gynaecol Can 2009; 31: 218-21.

3. Okafor UV, Efetie ER. Critical care obstetrics in a developing country. J Turkish-German Gynecol Assoc 2008; 9: 9-13.

4. Yıldıım G, Güngördük K, Aslan H, Gül A, Bayraktar M, Ceylan Y. Comparison of perinatal and maternal outcomes of severe preeclampsia, eclampsia, and HELLP syndrome. J Turkish-German Gynecol Assoc 2011; 12: 90-6. [CrossRef]

5. Khan KS, Wojdyla D, Say L, Gülmezoglu AM, Van Look PF. WHO analysis of causes of maternal death: a systematic review. Lancet 2006; 367: 1066-74. [CrossRef]

6. Aitken RC. Measurement of feelings using visual analogue scales. Proc R Soc Med 1969; 62: 989-93.

7. Zigmon AS, Snaith RP. The hospital anxiety and depression scale. Acta Psychiatrica Scand 1983; 67: 361-70. [CrossRef]

8. Bjelland I, Dahl AA, Haug TT, Neckelmann D. The validity of hospital anxiety and depression scale: an updated literature review. J Psychosomatic Res 2002; 52: 69-77. [CrossRef]

9. Martin CR, Tweed AE, Metcalfe MS. A psychometric evaluation of the hspital anxiety and depression scale in patients diagnosed with end-stage renal disease. Br J Clin Psychol 2004; 43: 51-64. [CrossRef]

10. Aydemir O, Guvenir T, Kuey L, Kultur S. Validity an reliability of Turkish version of Hospital Anxiety and Depression Scale. Turk Psikiyatri Derg 1997; 8: 280-7.

11. Weathers FW, Keane TM, Davidson JRT. Clinician administered PTSD scale: A review of the first ten years of research. Depr Anxiety 2001; 13: 132-56. [CrossRef]

12. Kocabasoglu N, Corapcioglu Ozdemir A, Yargic I, Geyran P. The validity and reliability of Turkish "PTSD Checklist-Civilian Version (PCL-C). New Symposium 2005; 43: 126-34.

13. Nizard J, Barrinque L, Frydman R, Fernandez H. Fertility and pregnancy outcomes following hypogastric artery ligation for severe post-partum haemorrhage. Hum Reprod 2003; 18: 844-48. [CrossRef]

14. Berkane N, Moutafoff-Borie C. Impact of previous uterine artery embolization on fertility. Curr Opin Obstet Gynecol 2010; 22: 242-47. [CrossRef]

15. Sentilhes L, Trichot C, Resch B, Sergent F, Roman H, Marpeau L, et al. Fertility and pregnancy outcomes following uterine devascularization for severe postpartum haemorrhage. Hum Reprod 2008; 23: 1087-92. [CrossRef]

16. Stone HL. Post-traumatic stress disorder in postpartum patients: what nurses can do. Nurs Womens Health 2009; 13: 284-91. [CrossRef]

17. Tham V, Christensson K, Ryding EL. Sense of coherence and symptoms of post-traumatic stress after emergency caesarean section. Acta Obstet Gynecol Scand 2007; 86: 1090-6. [CrossRef]

18. Olde E, Van Der Hart O, Kleber R, Van Son M, Wijnen H, Pop V. Peritraumatic dissociation and emotions as predictors of PTSD symptoms following childbirth. J Trauma Dissociation 2005; 6: 125-42. [CrossRef]

19. Beck CT. Post-traumatic stress disorder due to childbirth: the aftermath. Nurs Res 2004; 53: 216-24. [CrossRef]

20. Maggioni C, Margola D, Filippi F. PTSD, risk factors, and expectations among women having a baby: a two-wave longitudinal study. J Psychosom Obstet Gynaecol 2006; 27: 81-90. [CrossRef] 